\author{
井上 晃*,黒須立雄**, 青木 利昌**,二口政信**,

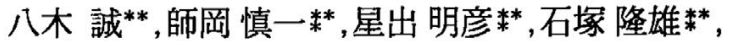 \\ 吉村邦広**, 吉田博之**, 光武 徹**, 安部 信明**, \\ 小島 章***,中島 毅**，中村 恵吕，沢 敏美**
}

（1994年 9 月20日 受理), (1995年 2 月 33日 再受理)

\title{
Void Measurement of BWR Fuel Assembly
}

By Akira INOUE, Tatsuo KUROSU, Toshimasa AOKI, Masanobu FUTAGUCHI, Makoto YAGI, Shinichi MOROOKA, Akehiko HOSHIDE, Takao ISHIZUKA, Kunihiro YOSHIMURA, Hiroyuki YOSHIDA, Toru MITUTAKE, Nobuaki ABE, Akira KOZIMA, Tuyoshi NAKAJIMA, Satoshi NAKAMURA and Toshimi SAWA

Steam void fraction measurement test in a BWR fuel assembly has been carried out to prove the current BWR void prediction method. This report describes the experimental apparatus, experimental data, and evaluation results.

The test was carried out in an out-of-pile test facility that can simulate the high pressure and high temperature conditions of BWRs. Water was used as a coolant. The void distribution in a BWR fuel assembly under BWR operating conditions was measured for the first time by an X-ray CT scanner, using an electrically heated test assembly which simulated a BWR fuel assembly on a full scale. Void fraction under steady and unsteady conditions was measured by an X-ray CT scanner and an X-ray densitometer.

In steady state void test, 476 data were obtained. These data were compared with the current BWR void prediction method. Unsteady void test data were evaluated with the unsteady analytical code.

It has been proved from these evaluation results that the verification of the current BWR void prediction method and unsteady analytical code has been accomplished.

KEYWORDS : BWR type reactors, fuel assemblies, thermal-hydraulics, void fraction, $X$-ray CT scanner, void distribution, subchannel analysis, void correlation, reliability

\section{I. 緒言}

沸騰水型原子力発電所(BWR)において，炬心 の冷却水は燃料集合体で発生した熱を除去する役 割のほかに，中性子の減速材としての機能む有す るので, その挙動は原子炉の設計および運転にお いて重要である。特に冷却水中の蒸気ボイド(以 下,ボイド)挙動は，BWR炉心の核熱水力特性に 影響を及ぼすので，炉心設計および運転上重要な パラメータのひとつである。

BWR の炉心設計において用いられているボイ
ド率評価式の信頼性は, 運転実績, 起動試験デー 夕等により確認されているが, 冷却水のボイド挙 動は炬心の核熱特性に大きな影響を及ぼすので, 今後の炬心燃料の高度化と, 上り一層の信頼性向 上を図るために，燃料集合体のボイド挙動を充分 に把握しておくことは有益である。

模擬燃料集合体内のボイド率测定は, Nylund ${ }^{(1)}$ により中心部に非加熱ロッドを有した

\footnotetext{
* 東京工業大学 (Tokyo Inst. of Technol.)

** (狽)原子力発電技術機構 (Nucl. Power Eng. Corp.)

** (侏東芝 (Toshiba Corp.)
} 
36本を同心円上に配置した試験体で実施されてい るが，この試験体はBWR 燃料集合体を模擬した ものではない。また，著者の一人 ${ }^{(2) ~(4)}$ が改良し たX線 CT スキャナを用いて, BWR 燃料集合体 を模擬した $4 \times 4$ 試験体を用いてボイド率分布を 測定している。しかし, 試験圧力は $1 \mathrm{MPa}$ であ り，BWRの通常運転圧力 $7 \mathrm{MPa}$ と異なってお り，現在のところBWR 運転条件下で実規模模擬 燃料集合体のボイド率測定結果については, 著者 の知る範囲では報告されていない。

この認識を踏まえ，BWR 燃料集合体のボイド 率評価手法の信頼性を確認するとともに，将来の 炬心燃料の高度化に備えて, 管群ボイドデータの 充実と評価手法の信頼性向上を図ることを目的と $し て ，$ 実規模の模擬燃料集合体 (以下, 試験体) 用いて，定常時および非定常時のボイド率を測定 する BWR 燃料集合体管群ボイド試験(以下，管群 ボイド試験)を実施した。試験は(財)原子力発電技 術機構が磯子工学試験所に設置した最大熱負荷試 験設備を使用し，ボイド率は X 線 CTスキャナお よびX 線密度計により測定した。

試験では，原子炬と同じ高温高圧条件を模擬で きる高温高圧水ループを使用し，間接通電加熱に より原子灯中の燃料集合体の発熱状態を模擬でき る 5 種類の試験体を使用し，模擬燃料集合体の定 常時扔上び非定常時のボイド率特性を，压力，冷 却材流量および入口温度ならびに出力を変化させ 種々な条件下で測定した。さらに，試験で得られ
たデータに基づいて，BWRボイド率評価式の信 頼性実証,管群体系のボイド率データベースの確 立，過渡・事故解析評価手法の信頼性実証および サブチャンネル解析手法の信頼性確認を行った。 本報では，BWRボイド率評価式の信頼性実証お よび過渡・事故解析評価手法の信頼性実証につい て説明する。

本試験は，(財)原子力発電技術機構が通商産業省 の委託により実施した。

\section{I. 試験 設 備}

\section{1. 試験装置(5)}

Fig. 1 亿試験装置の系統図を示す。装置の主要 構造材はSUS304である。冷却材としては純水を 使用した。この装置の最高使用可能条件は, 圧力 $10.3 \mathrm{MPa}$, 温度 $315^{\circ} \mathrm{C}$, 出力 $12 \mathrm{MW}$ 抢よび流量 33 $\mathrm{kg} / \mathrm{s}$ である。冷却水は, 循環ポンプ(1)によって 循環され，試験部流量は弁(3)により，また試験部 入口流体温度は, 直接通電加熱型予熱器(4)により それぞれ制御した。試験体に流入したサブクール 水は, 試験部(5)昇するに従い，加熱され蒸気 一水混合の二相流となり, 試験部上部より出た後, 蒸気ドラム8に蔵された気水分離器(7) に入る。 分離された蒸気の方は，蒸気ドラム(8)の上部空間 に扔いてスプレイ水によって凝縮し，気水分離さ れた水と合体して循環ポンプ(1)戻り, 同様なサ イクルを繰り返す。ループ全体の圧力は蒸気ドラ

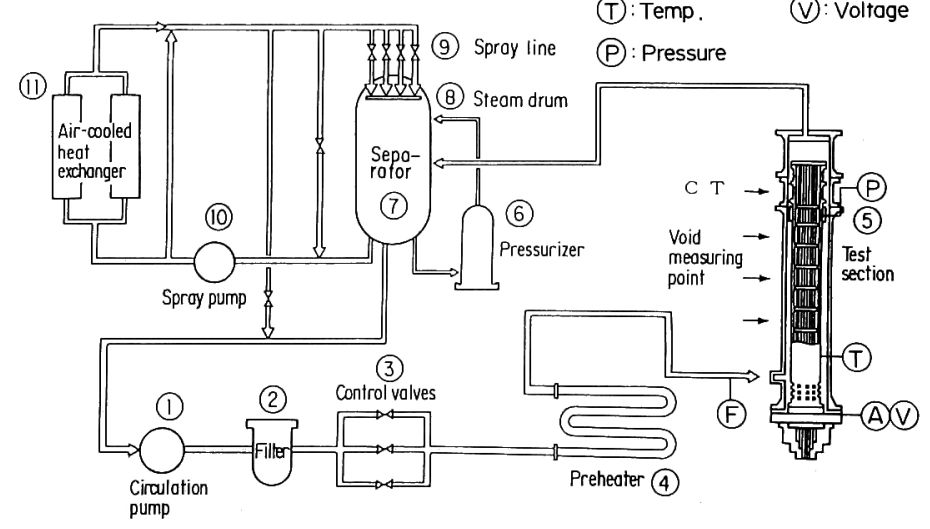
(F): Flow rate
(A): Amper
(T): Temp.
(v): Voltage

(11)

Fig. 1 System diagram of test facility 
ム内のスプレイ流量を変えて制御するが, 微調整 は加圧器(6)より行った。

試験装置は, BWR 運転範囲状態での定常試 験，または，例えば, 流量変化，出力変化および BWR 過渡変化のような非定常試験を実施する能 力を有している。

\section{2. 試験部および試験体}

試験部は, Fig. 2 に示すように, 実寸大の BWR 燃料集合体を模擬した試験体 1 体を高温, 高圧水流中において電気により加熱し, 沸騰二相 流の各種流動条件下でのボイド率を測定するため の設備で, 試験体、圧力容器,チャンネルボック ス，接続電極および式験体と圧力容器のシール部 冷却装置などから構成されている。試験体は実寸 大模擬燃料棒を $8 \times 8$ 正方格子状に配列したもの で，模擬燃料棒は，Fig. 3 に示すように，(+) 極, (一)極之も模擬燃料棒の下部より取り出す間 接発熱型のヒータである。被覆管,絶縁材および ヒータの材質はそれぞれインコネル，BN(ボロン

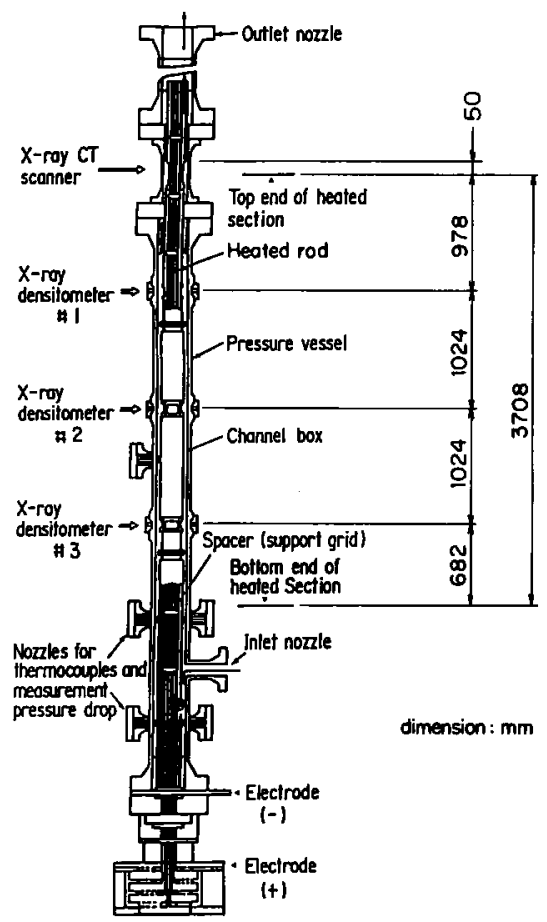

Fig. 2 Test section

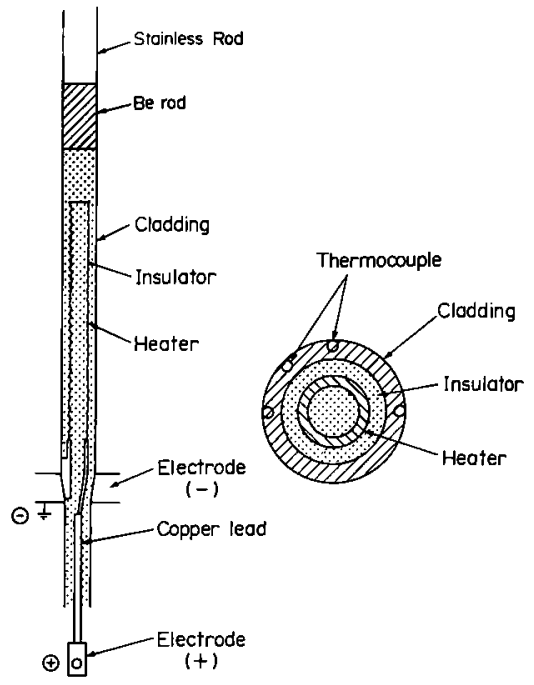

Fig. 3 Cross-sectional view of heater rod

ナイトライドそしてニクロムである。軸方向出力 分布は，ヒータの抵抗を軸方向に変えることによ り設定した。ヒータを被覆管に組み込む前に軸方 向抵抗分布を実測し、抵抗分布より計算した出力 分布と計画値との差は士 $1 \%$ 以内であった。解析 にはこの実測した出力分布を使用した。使用後の 模擬燃料棒よりヒータを取り出し抵抗分布を実測 し, 使用前の出力分布とほとんど変化がないこと を確認した。模擬燃料棒表面温度は, 外径 0.5

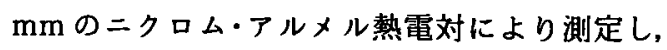
おのおのの熱電対はロッド表面に埋め込まれ，ス ペーサの直上流に設置した。各模擬燃料棒は, 外 径がヒータロッドと同じで, BeでできたX線透 過部と連結した。

Fig. 2 に示すように, 試験体発熱端における流 路断面内のボイド率分布を詳細に測定するため に, X 線 CTスキャナを設㯰した。一方, 非定常 時の軸方向ボイド率分布を測定するために，X線 密度計 3 台を軸方向に等間隔に設置した。X 線 密度計ではロッドとロッドの間の線分平均ボイド 率を測定した。また，非定常ボイド率測定時には $\mathrm{X}$ 線 CT スキャナは回転させず，静止状態のまま で多ビームX線密度計として使用し，断面平均ボ イド率の時間変化を測定した。Fig. 4 (a), (b)には $\mathrm{X}$ 線 CT スキャナと X 線密度計の测定部を示す。 


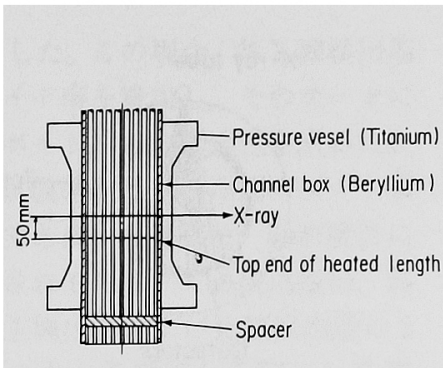

(a) X-ray CT scanner

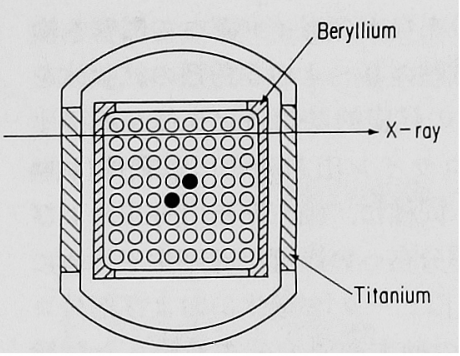

(b) X-ray densitometer

Fig. 4 Void measuring section

構造材部での X 線の減衰を極力避けるため, $\mathrm{X}$ 線透過パスのロッドおよびチャンネル壁は Beで, 圧力容器は $\mathrm{T}$ 合金で製作した。試験体は新型 8 $\times 8$ および高燃焼度 $8 \times 8$ 燃料集合体の形状を実 寸で模擬したあのである。
Table 1 に試験体の仕様を, Fig. 5 に新型 $8 \times 8$ 型燃料および高燃焼度 $8 \times 8$ 型燃料の試験体断面 形状を径方向出力分布とともに示す。両者の違い は，バンドル中央部分の非加熱ロッドの本数およ び径,加熱ロッドの本数である。試験では，燃料

Table 1 Test assemblies

\begin{tabular}{|c|c|c|c|c|c|}
\hline Test assembly No. & 0 & 1 & 2 & 3 & 4 \\
\hline Fuel Type & \multicolumn{4}{|c|}{ 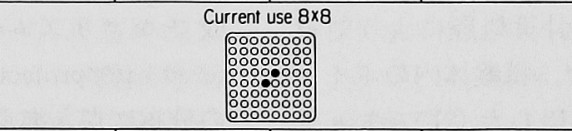 } & 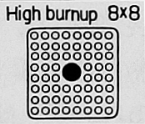 \\
\hline $\begin{array}{l}\text { Planar power } \\
\text { profile }\end{array}$ & Uniform & $\begin{array}{c}\text { Simulated design } \\
\text { profile }\end{array}$ & $\begin{array}{l}\text { Simuloted design } \\
\text { profile }\end{array}$ & $\begin{array}{l}\text { Simulated design } \\
\text { profile }\end{array}$ & $\begin{array}{c}\text { Simulated design } \\
\text { profile }\end{array}$ \\
\hline $\begin{array}{l}\text { Axiol power } \\
\text { profile }\end{array}$ & Uniform & Cosine & Half-cosine & Inlet peok & Uniform \\
\hline Heoted length & Full & Full & Half & Full & Full \\
\hline $\begin{array}{l}\text { Axial powe } \\
\text { distribution } \\
\text { Axial }\end{array}$ & & & 5 & & \\
\hline
\end{tabular}

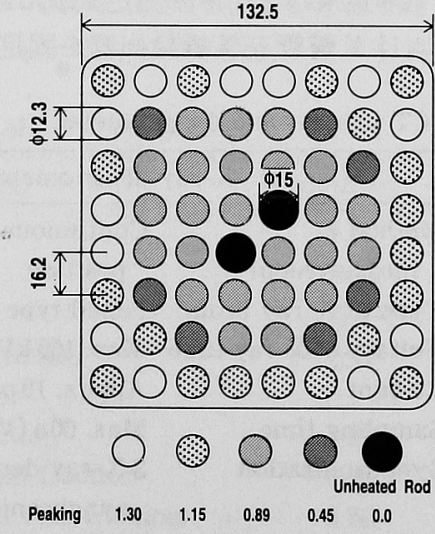

(a) Test assembly Nos. $1 \sim 3$

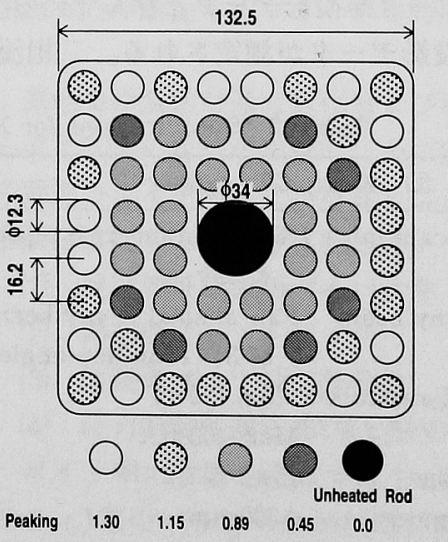

(b) Test assembly No. 4

Fig. 5 Radial power distribution (Dimension: $\mathrm{mm}$ ) 
形式および出力分布などのボイド率への影響を検 討するために，試験体 $0 \sim 4$ の 5 種類の試験体を 使用した。BWRの代表的な燃料集合体を模擬す るために軸方向コサイン出力分布の試験体 (試験 体 1)を使用した。同様に, 軸方向出力分布および 熱流束のボイド率分布への影響を評価するために 一様(試験体 0),入口ピーク (試験体 3 ) および部分コ サイン(試験体 2)の軸方向出力分布を持った試験 体を用いた。

\section{3. ボイド率測定システムと他の計測}

ボイド率測定システムは，X 線 CTスキャナ （以下,CTスキャナ)と X 線密度計よりなり，い ずれもX 線が試験部を透過する際の X 線強度の 減衰率からボイド率を測定するものである。 Table 2 (a),(b)にX線CTスキャナおよびX 線密 度計の基本仕樣を示す。 $\mathrm{X}$ 線 $\mathrm{CT}$ スキャナは対象 物周囲の多方面加 X 線を照射し, 対象物を透 過したX線強度を測定し, 計算炕理により対象 物の断面像を作成する装置で, 試験体内のボイド 率分布の測定に用いた。使用したCTスキャナ は, X 線管と512個の主検出器およびX線源の強 さをモニタする比較検出器がフレームに取り付け られている。

CTスキャナの測定原理の概要をFig. 6 を参考 にして説明する。回転(スキャン)中，扇状の X 線 ビームが対象物に照射され, 透過 $\mathrm{X}$ 線強度が㭘 出器によって検出される。検出器によって検出さ れたX線強度データを投影データと呼んでいる。 $360^{\circ}$ にわたり投影データが測定される。二相流

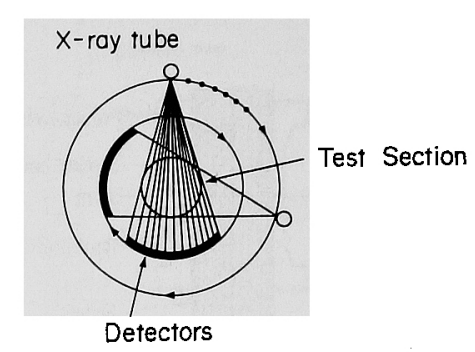

Fig. 6 Scanning method

の動きによる投影データへの影響を避けるため に, 著者の一人が開発 ${ }^{(2) \sim(4)}$ した時間平均測定法 を使用した。著者の一人が報告しているように, 二相流のような動的物体の物理量の時間平均値を 求める場合, 投影データが時間平均值である必要 があり,そのためボイド率測定では, 複数回ス キャンを繰り返し実行し，投影データの平均化姏 理を行っている。平均化された投影データは, CTスキャナのデー夕処理装置に送られ画像再構 成アルゴリズム(核医学で広く使用されている filtered back projection)によって線吸収係数 $\left(\mathrm{cm}^{-1}\right)$ の分布に書き換え，最終的にボイド率分布に変換 した ${ }^{(2)}$ 。基本的には，どのような流動様式，流路 形状であ適用可能であり(ただし，定常二相流に限 る), 本装置では $0.3 \mathrm{~mm} \times 0.3 \mathrm{~mm}$ の空間分解能 (画素)で局所ボイド率分布が測定可能である。X 線CTスキャナの検出器からのすべての測定デー 夕はSN比を改善するため, リファレンス検出器 のデータで補正した。

非定常時ボイド率湘定試験において，本システ ムは X 線管と X 線検出器を固定し多ビーム X 線

Table 2 Specifications for X-ray CT scanner and densitometer

\begin{tabular}{|c|c|c|c|}
\hline \multicolumn{2}{|c|}{ (a) X-ray CT scanner } & \multicolumn{2}{|c|}{ (b) X-ray densitometer } \\
\hline Method of scanning & $\begin{array}{l}360^{\circ} \text { rotation with pulse } \\
\quad \mathrm{X} \text {-ray }\end{array}$ & $\begin{array}{l}\text { Method of } \\
\text { measurement }\end{array}$ & $\begin{array}{l}\text { Continuous X-ray at fixed } \\
\text { position }\end{array}$ \\
\hline Type of X-ray beam & $\begin{array}{c}\text { Fan-shaped X-ray beam } \\
\text { of } 34^{\circ} \text { radiation angle }\end{array}$ & $\begin{array}{l}\text { Type of X-ray beam } \\
\text { Voltage of X-ray tube }\end{array}$ & $\begin{array}{l}\text { Pencil type beam } \\
\text { Max. } 160 \mathrm{kV}\end{array}$ \\
\hline Voltage of X-ray tube & Max. $120 \mathrm{kV}$ & Current & Appox. $19 \mathrm{~mA}$ at $160 \mathrm{kV}$ \\
\hline Current & Max. $400 \mathrm{~mA}$ & Sampling time & Max. $60 \mathrm{~s}$ (Variable) \\
\hline Scanning time & $15 \mathrm{~s}$ & Synchronization & $3 \mathrm{X}$-ray densitometers \\
\hline Scanning region & $\phi 300 \mathrm{~mm}$ & & synchronize with X-ray \\
\hline $\begin{array}{l}\text { Dimensions of recon- } \\
\text { struction element }\end{array}$ & Appox. $0.3 \mathrm{~mm} \times 0.3 \mathrm{~mm}$ & & $\begin{array}{l}\text { CT scanner for data } \\
\text { gathering }\end{array}$ \\
\hline
\end{tabular}


密度計として使用した。この場合, 各 X線検出器 ごとの線分平均ボイド率を算出し，そのデータに 基づいて断面平均ボイド率の時間変化を求めた。

$\mathrm{X}$ 線密度計は, 試験体模擬燃料棒間のボイド率 測定に用いるあのである。X線管は，各密度計に それぞれ 1 つ設置されている。X 線検出器は, 各 密度計に対して, 主検出器および比較検出器の 2 チャンネルが設置され，X 線管から発した X 線 は, ペンシルビームにコリメートされ, 試験部を 透過したのち主検出器に入射する。比較検出器 は, 主検出器と同一材料で作られ，X線変動をモ ニタするため，X線管の開口付近に設置した。主 検出器および比較検出器によって検知されたデー 夕は，それぞれ独立にデー夕収集装置内で積分， $\mathrm{A} / \mathrm{D}$ 変換し, $\mathrm{X}$ 線密度計用デー夕処理装置に収 録した。収集された各密度計の $\mathrm{X}$ 線検出器デー タがボイド率デー夕処理装置に転送され，各位置 でのボイド率を算出した。

ダイヤフラム式の変換器で圧力, 差圧計湘を 行った。試験部入口流量は,タービン流量計を用 いて計湘した。入口流体温度は測温抵抗体を用い て測定した。試験体出力は, 電圧そして電流測定 系によって得られた電流より計算で求めた。測定 値の精度をTable 3 に示す。ボイド率の測定精度 はX線つォトンの統計的な变動,計測系の系統的 誤差および流体条件の湘定誤差により算出した。 この測定精度は，実際のボイド率測定部の断面寸 法および材料で製作し，ボイドパターン（気泡流， 環状流ををアクリル片によって模擬した模型で確 認した ${ }^{(6)}$ 。サブチャンネルおよび断面平均ボイド

Table 3 Accuracies

\begin{tabular}{lc}
\hline \multicolumn{1}{c}{ Quantity } & Accuracy \\
\hline Pressure & $1 \%$ \\
Flow & $1 \%$ \\
Power & $1.5 \%$ \\
Inlet fluid temperature & $1.5^{\circ} \mathrm{C}$ \\
X-ray CT scanner & \\
$\quad$ Local void fraction & $8 \%$ \\
Subchannel void fraction & $3 \%$ \\
$\quad$ Cross-sectional void fraction & $2 \%$ \\
X-ray densitometer chordal void & \\
$\quad$ fraction & $2 \%$ \\
\hline
\end{tabular}

率は，各画素(測定の最小単位は，Table 2 に示すよ うに，0.3mmである)での局所ボイド率を面積積分 することにより求めた。

\section{III. 試験の種類と条件}

次の 2 種類の試験を行った。

\section{1. 定常時ボイド試験}

ボイド率特性に影響を及ぼす可能性のある試験 体形状，軸方向および径方向出力分布ならびに流 体条件をパラメータにし，実規模模擬然料集合体 内のボイド率を $\mathrm{X}$ 線 CTスキャナおよび X 線密度 計を使って測定した。流体条件として圧力，流量 およびクォリティについては，実炉の運転範囲を 包含する下記の条件で, 合計476点のデータを测 定した。

圧力 : $1 \sim 8.6 \mathrm{MPa}$

流量 : $284 \sim 1,988 \mathrm{~kg} / \mathrm{m}^{2} \cdot \mathrm{s}$

クォリティ：1〜25\%

ここで，クォリティは然料集合体加熱端での断 面平均熱平衡クォリティの値。

\section{2. 非定常時ボイド試験}

試験では，圧力,流量,出力の各パラメータの非 定常時断面平均ボイド率挙動に及ぼす影響を調べ る単純過渡事象の試験および, 出力, 圧力, 流量等 のパラメータ変化を組み合わせた複合過渡事象の 試験を実施し，非定常時における実規模模擬燃料 集合体内の断面平均ボイド率の時間变化を測定し た。

運転時の異常な過渡変化および事故のうち，炉 心ボイド率の変化が顕著で, かつ中性子動特性之 の関連でボイド率変化が重要となる以下の 4 つの 事象を模擬する試験を実施した。

（1）発電機負荷遮断バイパス弁不作動

(2) 再循環ポンプトリップ

(3) 再循環ポンプ軸固着事故

（4）王力制御装置故障(增加要求)

ボイド率に影響を及ばす圧力，流量，出力(クォ リティ）等のパラメータが同時に変化する複合過 渡事象の試験では, 複数のパラメータの影䈏が重 複するので,ボイド挙動の基本特性を把握するこ 
とが難しい。そこで，重要なパラメータを個別に 変化させる単純過渡事象の試験す併せて実施し た。すなわち、ボイド挙動に重要なパラメータと しては，圧力，流量、出力が挙げられ，これらのパ ラメータが単独で変化する場合の試験を行った。

\section{IV. 試験 結果}

\section{1. 定常時ボイド率分布}

\section{（1）局所ボイド率分布}

Photo. 1 (a)〜 (c)k，圧力，質量速度をそれぞれ $7.2 \mathrm{MPa}, 1,614 \mathrm{~kg} / \mathrm{m}^{2} \cdot \mathrm{s}(\mathrm{BWR}$ 定格運転状態)に

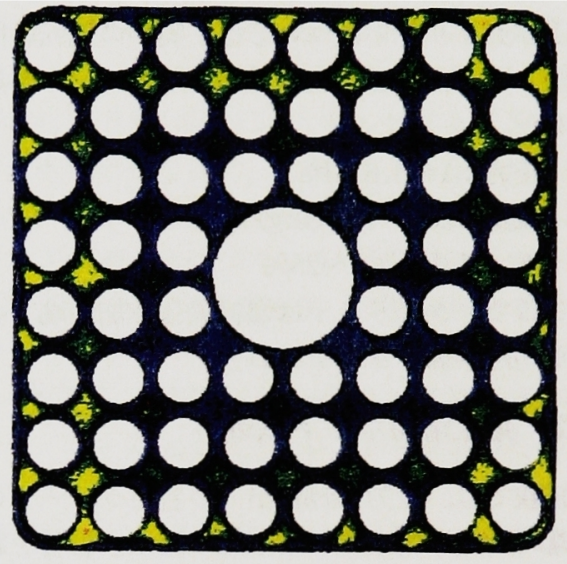

(a) Quality : $X=2 \%$

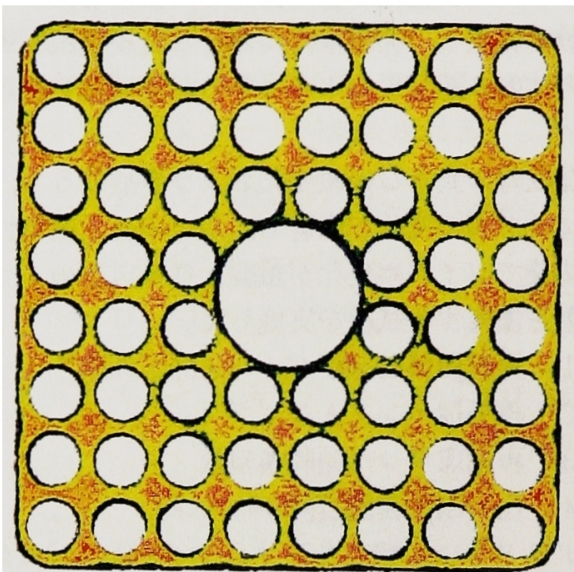

(b) Quality : $X=8 \%$
し，測定部の断面平均クォリティ（熱平衡クォリ ティ)を $2,8,18 \%$ に変化させた場合のX線 CTス キャナで測定された代表的な局所ボイド率分布を 示す。この結果は, Fig. 5 (b)に示す高燃焼度 $8 \times$ 8 然料の場合である。ボイド率の值はカラーで区 別されている。ただし，ロッドの部分は流路とを 区別するために白とした。クォリティが $2 \%$ 場 合(Photo. 1 (a))，Fig. 5 に示すように，高出力 ロッドが最外周に配列されているため最外周流路 にボイドが多く生じているが，クォリティが $8 \%$ に上昇すると(Photo. 1 (b))，燃料集合体全体でボ イド率が増大し，ボイドは高出力ロッドで囲まれ たサブチャンネルに極端に集中していないことが わかる。加えて, チャンネル壁および中央の非加 熱棒表面には液膜と思われる低いボイド率の領域 が存在している。さらに, クォリティが12\%に上 昇すると (Photo. 1(c))，かなり均一なボイド率分 布になり，ロッド表面には液膜と思われる領域が 存在するようになり，流動様式は環状流と推定さ れる。通常，BWR然料でドライアウトが発生す るクォリティは $12 \%$ 以上であり，このボイド率分 布の結果より，BWR然料ではドライアウトが発 生する流動様式は環状流であることがわかる。

(2) 断面平均ボイド率に対する 各パラメータの影零

冷却材条件(流量,圧力,クォリティ)による断面平

Pressure : 7.2 MPa, Mass flux : $1,562 \mathrm{~kg} / \mathrm{m}^{2} \cdot \mathrm{s}$, Test assembly : High burn-up $8 \times 8$

Photo. 1 Typical local void fraction distribution by X-ray CT scanner 
均ボイド率への定性的な影響は試験体により変化 がないのでここでは試験体 0 のデー夕を示す。 Fig. 7 に，いろいろな圧力における断面平均ボイ ド率(ボイド率)とクォリティの関係を示す。ボイ ド率はクォリティの増加ととあにボイド率が急激 に增大する低クォリティ域から，ボイド率が秪や かに增加する高クォリティ域へ之移行していく。 また，Fig. 7より，流量、クォリティが一定の条 件では, 圧力が増加するに従いボイド率も減少す る。これは, 圧力が増加するに従い蒸気の比容積 が減少するためと考えられる。Fig.8にボイド率 に及ぼす流量の効果を示す。流量の增加に従い, ボイド率は增大している。これは一定圧力, そし て一定クォリティにおいて流量を増加していく と, 液流速とミキシングの増大によりスリップ比

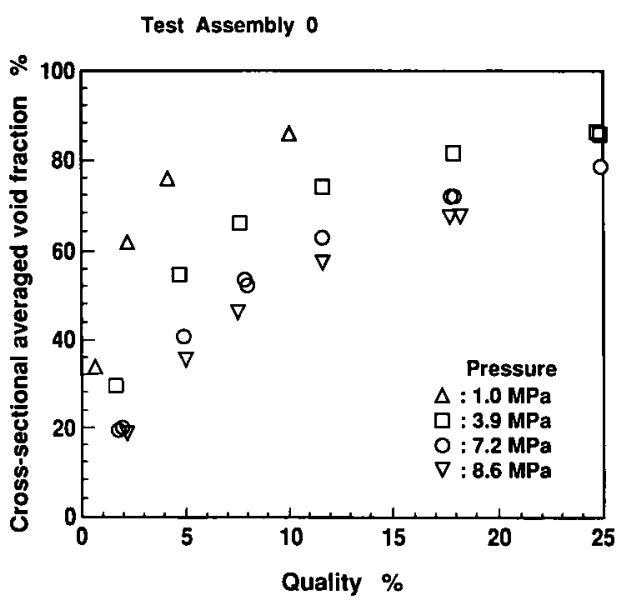

Fig. 7 Effect of pressure and quality on void fraction

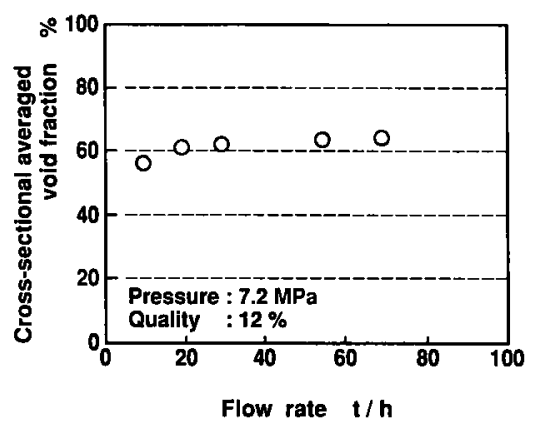

Fig. 8 Effect of flow rate on void fraction
が次第に小さくなるためと考えられる。上述した 冷却材条件による断面平均ボイド率への影響は, 円管、矩形管などの単純流路の場合と同じであ $3^{(7)}$ 。

Fig.9は，横軸にフロークォリティを，縦軸に 断面平均ボイド率をとり, 燃料型式の断面平均ボ イド率への影響を示したむのである。図中，○印 は従来型 $8 \times 8$ ，○印は高燃烧度 $8 \times 8$ の試験結果 を示している。両者とも,クォリティとボイド率 との関係は，低クォリティ領域でボイド率はクォ リティとともに急激に増大するが, 高クォリティ 領域ではボイド率のクォリティに対する感度は小 さくなっている。また, 同じクォリティにおける 両者のボイド率の差は小さく, 燃料型式の断面平 均ボイド率への影響は無視できるほど小さいと考 えられる。

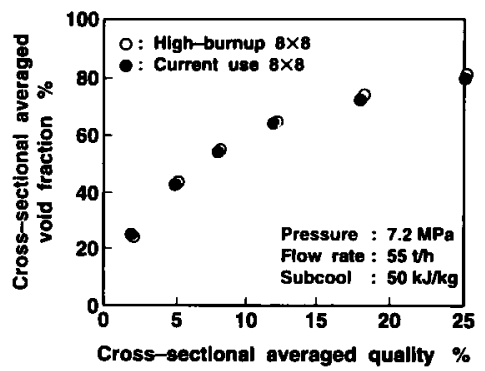

Fig. 9 Effect of fuel type on void fraction

Fig.10は, 横軸にフロークォリティを, 縦軸に 断面平均ボイド率をとり, 軸方向出力分布の断面 平均ボイド率への影響を示したものである。同じ クォリティにおける両者のボィド率の差は小さ く, 軸方向出力分布の断面平均ボイド率への影響

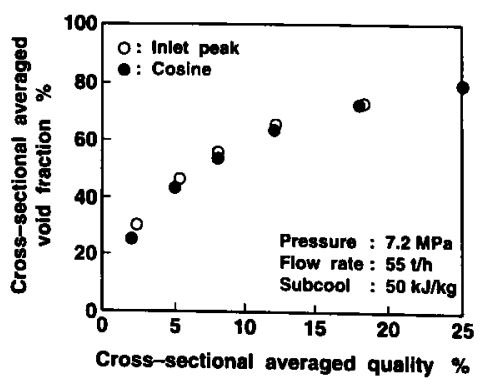

Fig. 10 Effect of axial power shape on void fraction 
は無視できるほど小さいと考えられる。この結果 より，本試験範囲内では，断面平均ボイド率はそ の位置における流体条件により規定され，上流の 影響は小さいと思われる。

\section{(3) 断面平均ボイド率計算式の評価}

BWRに㧍けるボイド率評価式は，ドリフトー フラックス・モデルに基づいている。ZuberFindlay ${ }^{(8)}$ が最初に導出したドリフトーフラック ス・モデルの基本式は，次式で表せられる。

$$
\begin{aligned}
& a=\frac{x}{C_{0}\left[x+(1-x) \rho_{G} / \rho_{L}\right]+\rho_{G} V_{G j} / G} \\
& \text { ここで， } \alpha \text { : 断面平均ボイト率 } \\
& C_{0}: \text { 分布パラメー夕 } \\
& V_{G j}: \text { ドリフト速度 }(\mathrm{m} / \mathrm{s}) \\
& G \text { : 質量流束 }\left(\mathrm{kg} / \mathrm{m}^{2} \cdot \mathrm{s}\right) \\
& x: \text { 断面平均クォリティ } \\
& \rho_{\mathfrak{L}}, \rho_{G}: \text { 水および蒸気の密度 }\left(\mathrm{kg} / \mathrm{m}^{3}\right)
\end{aligned}
$$

BWRに㧍けるボイド率評価式は上記のZuberFindlay 式を修正したもので，分布定数 $C_{0}$ は クォリティおよび蒸気と水の密度比の関数として 表現され，ドリフト速度は次式より計算される。

$$
\begin{gathered}
V_{G j}=K\left[\frac{\sigma\left(\rho_{L}-\rho_{G}\right)}{\rho_{L}}\right]^{1 / 4} \\
\text { ここで, } K: \text { 実験定数 } \\
\sigma: \text { 表面張力 }(\mathrm{N} / \mathrm{m})
\end{gathered}
$$

Fig.11 は評価式と本研究で X 線 CT スキャナで 測定した全データ (厌力：1 8.6 MPa, 流量 : 284〜 $1,988 \mathrm{~kg} / \mathrm{m}^{2} \cdot \mathrm{s}$, 熱平衡クォリティ: 1 25\%)との比較 を示す。全体的に, 評価式はデー夕と良好に一致

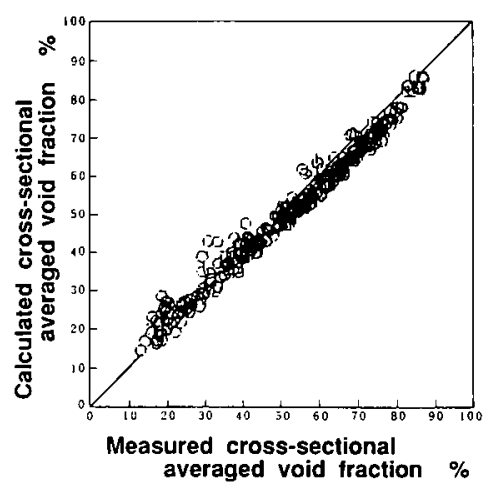

Fig. 11 Comparison of all data with BWR void prediction method
しているが，60\%以上の高いボィド率領域では， この式は測定值を過小評価する。他方，40\%以下 の低ボイド率領域では若干過大評価する。この式 の精度を定量的に評価するために以下の量を用い た。

$$
\Delta \alpha=\text { 测定値一計算値 }
$$

データとの比較より，BWRにおけるボイド率 評価式は, BWR 燃料集合体の断面平均ボイド 率を系統誤差 $(\Delta a)$ の平均値 $2.1 \%$,標準偏差 $(\sigma)$ $3 \%$ で予想でき, 断面平均ボイド率の測定精度 （Table 3）2\%を考虑すれば，評価式はBWR然料 集合体の断面平均ボイド率を満足できる精度で予 测できると考えられる。

次に, 従来の相関式と本試験データとの比較を 行った ${ }^{(9)}$ 。比較に用いた相関式は, 均質流モデ ル, Bankoff 式(10)，Zuber-Findlay 式(8)おむび EPRI 式 ${ }^{(11)(12)}$ である。Table 4 に各相関式の予測 精度を統計的に評価したものを示す。またFig.12 には，この表より最す予測精度が良いEPRI式と データとの比較を示す。この式の場合, $\Delta a$ の平 均が $-2.3 \%$,標準偏差 $\sigma$ が $2.2 \%$ ある。

Table 4 Evaluation of void correlations

\begin{tabular}{lrc}
\hline \multicolumn{1}{c}{ Correlation } & $\overline{\Delta \alpha}(\%)$ & $\sigma(\%)$ \\
\hline Homogeneous & -10.5 & 4.5 \\
Bankoff $^{(9)}$ & 2.7 & 5.4 \\
Zuber-Findlay $^{(7)}$ & 1.5 & 3.9 \\
EPRI $^{(11)(12)}$ & -2.3 & 2.2 \\
\hline
\end{tabular}

Data points : 476

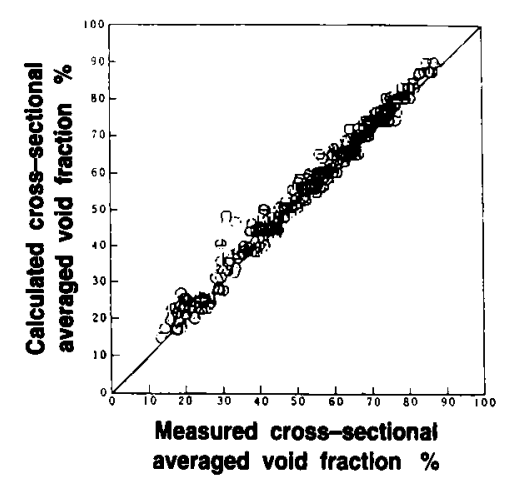

Fig. 12 Comparison of all data with EPRI void correlation 


\section{2. 非定常時ボイド率測定試験}

\section{(1) 概 要}

この試験で測定される主なデータは，流量，圧 力,出力, 入口温度,加熱端でX線 CT スキャナで測 定された断面平均ボイド率および線分平均ボイド 率から評価された断面平均ボイド率の時間変化で ある。

解析コードとしては, 非均質, 非平衡状態を取 り扱える見象解析コードであるRELAP5/MOD2 コード(13)を用いた。

(2) 検 討

Fig.13 に代表的な複合過渡事象の試験結果の うち，再循環ポンプトリップ(ポンプ慣性 $1 \mathrm{~s}$ ) 事象 を模擬した試験の測定値之計算結果との比較を示 す。Fig. 13(a)はパラメータ変化を，Fig. 13(b)は 断面平均ボイド率の測定值と計算値の比較を示 す。図中, 測定結果および計算結果とも初期値か らのボイド率変化幅を示している。この事象では 再循環ポンプがトリップし，ポンプ慣性を小さく
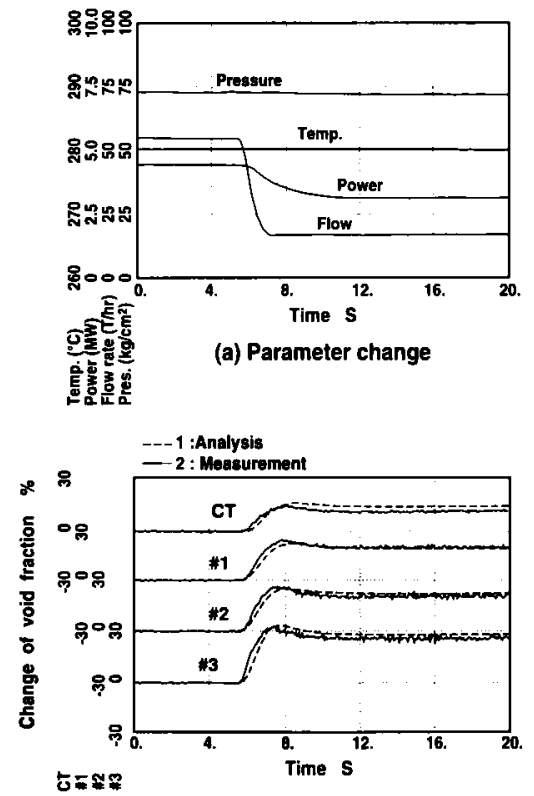

(b) Change of the cross-sectiona averaged void fraction

Fig. 13 Comparison of void data for recirculation pump trip event (pump inertia time 1s) with RELAP5/MOD2
仮定しており，流量が急減する。流量が急減する ため、ボイド率は増加している。ボイド率の増加 により出力は減少する。出力の減少は流量減少に 比較してゆっくりしているため，ボイド率は大き く増加する。測定されたボイド率の時間変化もこ の傾向になっている。一方, 計算結果之測定値の 傾向は計算值が若干高めであるが，全体としては 良好に一致している。その他の試験ケースについ ても同様な評価および検討を行い，計算值と測定 値は同程度の一致を示すことを確認している。

Fig.14は，過渡変化時におけるボイド率変化 の最大值の計算値と測定値との比較を示したもの であり，ほぼ良好に両者は一致している。

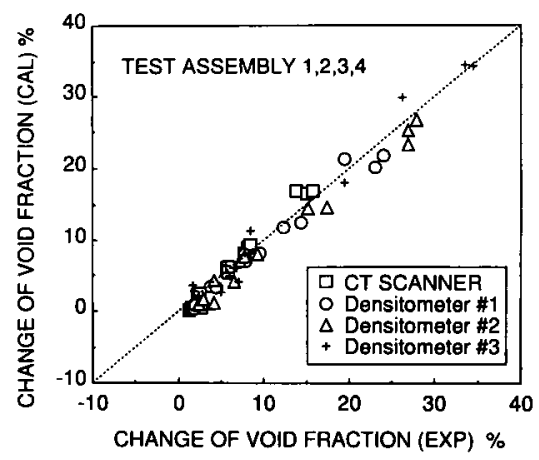

Fig. 14 Comparison between RELAP5/MOD2 and measured change of void fraction

\section{V. まとめ}

BWR 燃料集合体の定常時, 非定常時の冷却材 ボイド特性データを得ることができた。これらの データを詳細に解析および評価を行った結果, 定 常時および非定常時のボイド率の評価手法の妥当 性を確認できた。

本試験の成果に関する具体的内容を要約すれば 次の通りである。

\section{（1）試験データの信頼性}

BWR 運転時における高温高圧の熱水力条件を 実現できる試験設備(管群ボイド試験設備)に，実機 の燃料集合体の形状および発熱分布を模擬した燃 料集合体 1 体を装荷し, 電気加熱により発熱さ せ，定常時ボイド試験および非定常時ボイド試験 でそれぞれ476，44ヶースの試験データを採取し 
た。

データ採取は, 計測機器の較正および再現性試 験を行うことにより正しくデータが採取されてい ることを確認した。また，一部の試験体について は試験後の検查を実施した結果，特に使用前の状 態と変化は認められなかった。この結果より, 本 試験で得られたデー夕は十分信頼性の高いあので あると考えられる。

\section{（2）解析との比較}

(a) 断面平均ボイド率の評価

BWRにおけるボイド率評価式による断面平均 ボイド率計算值と湘定值との比較によれば，全試 験データに対して(測定値一計算值)の偏り誤差は $2.1 \%$ ，標準偏差は $3.0 \%$ ある。ボイド率の測定 值を高ボイド率領域ではやや低めに予測する傾向 がみられるが，断面平均ボイド率の測定誤差 ( $\pm 2 \%)$ 等を考えると評価式として妥当であると 考えられる。

(b) 非定常時のボイド率の評価

4 種類の試験体を用いて合計44ケースの非定常 時試験を実施し，非均質・非平衡熱水力解析モデ ルに基づく解析コードRELAP5/MOD2による断 面平均ボイド率変化の計算結果は試駼結果と比較 的よく一致しており，解析コードの妥当性が確認 できた。

（3）管群体系のボイドデータベースの確立 実規模の模擬燃料集合体を用い，冷却材条件， 集合体流路形状，出力分布に関する種々のパラ メー夕をかえた試験を行い，管群体系のボイト率 データベースを構築した。本試験では，X線 CT
スキャナによるボイド率測定技術により，世界で 初めて集合体内の詳細なボイド率データを得るこ とができ, サブチャンネル解析の高度化等, 将来 の炬心燃料の高度化などに資することのできる貴 重なデータが蓄積できた。

本試験は煳原子力発電技術機構が通商産業省か らの委託により，多くの関係者の協力のもとに行 われたものであり, 著者らは本試験に参加頂いた 関係各位の協力に感謝するととあに, 本試験の成 果が今後の炬心燃料の開発に大きく寄与すること を期待したい。

\section{一参考文献一}

(1) Nylund, O.: Asea Res., 10, 63 (1969).

（2）飯塚 勝, 他：原子力誌，26 (5)，421 (1984).

(3) 師岡慎一, 他 : 同 上, $30[10], 925$ (1988).

(4) MoRooKA, S., et al. : Nucl. Eng. Des., 114, 91 (1989).

（5）秋山 守, 他：原子力誌, 31 (6), 280 295 (1989).

(6) MoRoOKA, S., et al. : ICONE-1, a-38, 237 243 (1991).

(7) 機械学会：“気液二相流技術ハンドブック”, 80 (1989), コロナ社.

(8) Zuber, N., Findlay, J. : Trans. ASME, Ser. $C$, 87, $453 \sim 468$ (1965).

（9）石塚隆雄, 他：原子力誌，37 [2]，133 (1995).

(10) Bankoff, S. G. : Trans. ASME, Ser. C, 82, 265 272 (1960).

(11) Chexal, B., Lellouche, G. : EPRI-NP-3989-SR (Rev.1), (1986).

(12) Chexal, B., et al. : NSAC-139, (1991).

(13) Ronsom, V. H., et al. : NUREG/CR-4312, (1985).

\section{〉講習会「最近の化学工学'95」一抽出}

主催 化学工学会関東支部，協賛 本会，ほ加 2 学会

会 期 1995年11月30日(木)，12月1日(金)

会 場 明治大学大学会館 5 陵会議室(卸茶の水) プログラム

I 、はじめに ( 2 件)

II. 抽出の基礎と最近の動向 ( 4 件)

III. 抽出技術の新展開 ( 7 件)

講習会テキスト「最近の化学工学一抽出」には,
付録：最近10年の基礎研究における抽出系一臨 (30ペーシ)が含まれます。

参加費(テキスト代含む)

協賛会員 $20,000 \mathrm{H}$ ，大学·公機関 $10,000 \mathrm{H，}$ 学生会員 2,000 円，会員外 30,000 円

テキストのみ 2,000 円(参加者)

申込先 （T112）東京都文京区小日向4-6-13 化学工学会 関東支部

(TEL 03-3943-3527 ; FAX 03-3943-3530； E-mail : LDF01757@niftyserve.or.jp) 